\title{
Risk behaviors for sexually transmitted diseases among crack users ${ }^{1}$
}

\author{
Rafael Alves Guimarães ${ }^{2}$ \\ Leandro Nascimento da Silva ${ }^{3}$ \\ Divânia Dias da Silva França ${ }^{4}$ \\ Nativa Helena Alves Del-Rios ${ }^{5}$ \\ Megmar Aparecida dos Santos Carneiro ${ }^{6}$ \\ Sheila Araujo Teles ${ }^{7}$
}

\begin{abstract}
Objectives: to investigate the prevalence and risk behaviors by means of reporting of sexually transmitted diseases among crack users. Method: cross-sectional study carried out with 588 crack users in a referral care unit for the treatment of chemical dependency. Data were collected by means of face-to-face interview and analyzed using Stata statistical software, version 8.0. Results: of the total participants, 154 (26.2\%; 95\% CI: 22.8-29.9) reported antecedents of sexually transmitted diseases. Ages between 25 and 30 years (RP: $2.1 ; 95 \% \mathrm{CI}: 1.0-4.0$ ) and over 30 years (RP: 3.8; 95\% CI: 2.1-6.8), alcohol consumption (RP: 1.9; 95\% CI: 1.1-3.3), antecedents of prostitution (RP: $1.9 ; 95 \% \mathrm{CI}: 1.3-2.9$ ) and sexual intercourse with person living with human immunodeficiency virus/AIDS (RP: $2.7 ; 95 \%$ CI: 1.8-4.2) were independently associated with reporting of sexually transmitted diseases. Conclusion: the results of this study suggest high risk and vulnerability of crack users for sexually transmitted diseases.
\end{abstract}

Descriptors: Crack Cocaine; Drug Users; Sexually Transmitted Diseases; Risk Factors.

\footnotetext{
${ }_{1}$ Supported by Conselho Nacional de Desenvolvimento Científico e Tecnológico (CNPq), Brazil, process \# 474713/2012-1.

2 Master's student, Faculdade de Enfermagem, Universidade Federal de Goiás, Goiânia, Go, Brazil.

3 Master's student, Faculdade de Medicina, Universidade Federal de Goiás, Goiânia, Go, Brazil.

${ }^{4}$ Doctoral student, Faculdade de Medicina, Universidade Federal de Goiás, Goiânia, GO, Brazil.

5 Doctoral student, Instituto de Patologia Tropical e Saúde Pública, Universidade Federal de Goiás, Goiânia, Go, Brazil.

6 PhD, Associate Professor, Instituto de Patologia Tropical e Saúde Pública, Universidade Federal de Goiás, Goiânia, GO, Brazil.

7 PhD, Associate Professor, Faculdade de Enfermagem, Universidade Federal de Goiás, Goiânia, GO, Brazil.
}

Corresponding Author:

Sheila Araujo Teles

Universidade Federal de Goiás. Faculdade de Enfermagem

Rua 227, Qd 68, S/N

Setor Leste Universitário

CEP: 74605-080, Goiânia, GO, Brasil

E-mail: sheila.fen@gmail.com
Copyright $\odot 2015$ Revista Latino-Americana de Enfermagem This is an Open Access article distributed under the terms of the Creative Commons Attribution Non-Commercial License (CC BY-NC).

This license lets others distribute, remix, tweak, and build upon your work non-commercially, and although their new works must also acknowledge you and be non-commercial, they don't have to license their derivative works on the same terms. 


\section{Introduction}

The crack first appeared in the United States of America (USA) in the early 80s, and since then, its use has expanded to all regions of the world, especially to South American countries(1). In 2008, a study conducted by the Ministry of Health, with individuals aged from 15 to 64 years, estimated that $2.6 \%$ of the Brazilian population have already used crack in life. In the Central-West region of Brazil, this estimate was $0.3 \%{ }^{(2)}$.

Crack use can cause extensive damage and health risks to users, such as acute and chronic complications(3), mental disorders and early death by murder and overdose ${ }^{(4)}$. Furthermore, many users have risk behaviors such as consumption of alcohol and other drugs $^{(5)}$, multiple partners, inconsistent condom use and prostitution ${ }^{(6)}$, which in turn, are associated with Sexually Transmitted Diseases (STD), including infection with Human Immunodeficiency Virus (HIV).

A number of studies have shown a high prevalence of STD in illicit drug users ${ }^{(7-9)}$. In the USA, a study of 266 crack users found positive cases for gonorrhea, syphilis, chlamydia, HIV, Hepatitis B Virus (HBV), Hepatitis C Virus (HCV) and Herpes Virus type 2 (HSV2 ), with prevalence rates of $1.9 \%, 3.8 \%, 4.5 \%, 4.1 \%$, $33.5 \%, 37.2 \%$ and $53.3 \%$, respectively ${ }^{(7)}$. In Argentina, HIV prevalence (6.3\%), HBV (9.0\%), HCV (7.5\%) and Venereal Disease Research Laboratory (VDRL) (4.2\%) were estimated in504 non-injectable cocaine users $^{(8)}$. In Brazil, an investigation with 125 crack users, in a community of Salvador, at the State of Bahia, estimated the prevalence of $\mathrm{HBV}, \mathrm{HIV}, \mathrm{HCV}$ and syphilis (VDRL), of $0.8 \%, 1.6 \%, 2.4 \%$ and $4.0 \%$, respectively ${ }^{(10)}$. In São Paulo, prevalence of $22 \%$ for STD reporting and of $6.6 \%$ for HIV were found in 304 institutionalized illicit drug users $^{(9)}$.

The number of studies on the epidemiology of STD in crack users is still limited ${ }^{(11-13)}$, and most of the ones conducted in Brazil was carried out in the most developed regions of the country (South and Southeast) $(5,9-10)$. In this respect, the objective of this study was to investigate the prevalence and risk behaviors by means of STD reporting in institutionalized crack users of Goiânia, Goiás, Central region of Brazil.

\section{Methods}

Cross-sectional study carried out with crack users, in a referral care unit for treatment of chemical dependency of the State of Goiás, between August 2012 and April 2013. The study included individuals aged 18 years or over and who had consumed crack for at least one month before hospitalization. Individuals were excluded if they were under influence of any medication at the time of the interview.

All eligible individuals were invited to participate in the study and were informed on the objectives, importance, benefits, risks and confidentiality of the data. If they agreed to participate, they signed the Free and Informed Consent Form (ICF), and then they were interviewed in a private place at the care unit.

The interviews were conducted using a research instrument adapted: "Profile of crack users in 26 capitals, Distrito Federal, nine metropolitan areas and Brazil"(14). The research instrument contains questions on socio-demographic characteristics (gender, age, skin color, marital status, education and income), pattern of consumption of licit and illicit drugs (drugs used and time of crack use) and risk factors for STD (prison record, condom use during sexual intercourse in the last six months, antecedents of prostitution, give money and/or drugs in exchange for sex, sex with a person living with HIV/AIDS, and others). It was considered as outcome variable the reporting of STD at some point in life, including HIV infection.

The data were analyzed using Stata statistic software, version 8.0. For the continuous variables, mean and standard deviation were calculated. The prevalence of STD reporting was estimated with $95 \%$ confidence interval (95\% CI). Initially, univariate analysis was performed, and then all variables with $p<0.10$ were included in the Poisson regression model. The chi-square test $(x 2)$ was used to analyze differences among proportions. Values with $\mathrm{p}<0.05$ were considered statistically significant.

The Committee of Ethics in Human and Animal Research, of the University Hospital of the Federal University of Goiás, approved this study, under the protocol number $117 / 2011$. All stages of the research meet the ethical principles that guide research in humans, described and established by Resolution CNS $196 / 96$.

\section{Results}

The study included 588 crack users. Most were male $(84.5 \%)$, single $(66.7 \%)$, with income of less than three minimum wages $(62.6 \%)$ and self-declared as dark-skinned/brown/mulatto $(61.7 \%)$. The average 
age of users was 30.5 years (SD \pm 8.3 ) and $45.4 \%$ of participants were older than 30 years. Regarding education, half of them $(50.3 \%)$ had more than eight years of study (Table 1 ).

Of the participants, 154 (26.2\%; 95\% CI: 22.8$29.9)$ reported that they had or still have a STD. Three hundred and twenty individuals (54.4\%; 95\% CI: 50.458.4) reported having previously been submitted to HIV test, and of these, $11(3.4 \%$; 95\% CI: $1.9-6.0)$ reported to have tested positive.

Table 2 shows the analysis of potential factors associated with STD reporting in the crack users investigated. In the univariate analysis it was found that age, marital status, prison record, antecedents of prostitution and sexual intercourse with a person living with HIV/AIDS were associated with STD reporting $(p<0.05)$. The variables time of crack use, alcohol consumption, use of condoms with a casual partner and give money and/or drugs in exchange for sex showed marginal association with the outcome. These variables were included in a multivariate analysis model, and after controlling the confounding variables, ages between 25 and 30 years (Prevalence Ratio: $2.1 ; 95 \% \mathrm{CI}: 1.0-4.0$ ) and over 30 years (Prevalence Ratio: 3.8; 95\% CI: 2.1-6.8), alcohol consumption (Prevalence Ratio: 1.9; 95\% CI: 1.1-3.3), antecedents of prostitution(Prevalence Ratio: $1.9 ; 95 \% \mathrm{CI}: 1.3-2.9$ ) and sexual intercourse with a person living with HIV/ AIDS (Prevalence Ratio: 2.7; 95\%CI: 1.8-4.2) were independently associated with STD reporting. The prison record showed a marginal association with the outcome (Prevalence Ratio: 1.5; 95\% CI: 1.0-2.2).

Table 1 - Socio-demographic characteristics of 588 institutionalized crack users. Goiânia, GO, Brazil, 2012-2013

\begin{tabular}{|c|c|c|}
\hline Characteristic & $\mathrm{n}$ & $\%$ \\
\hline \multicolumn{3}{|l|}{ Sex } \\
\hline Male & 497 & 84.5 \\
\hline Female & 91 & 15.5 \\
\hline \multicolumn{3}{|c|}{ Age (years) (mean: $30.5 ; \mathrm{SD} \pm 8.3$ ) } \\
\hline$\leq 24$ & 160 & 27.2 \\
\hline $25-30$ & 161 & 27.4 \\
\hline$>30$ & 267 & 45.4 \\
\hline \multicolumn{3}{|l|}{ Marital status } \\
\hline Single & 392 & 66.7 \\
\hline Married/unmarried union & 134 & 22.8 \\
\hline Separated/divorced & 62 & 10.5 \\
\hline \multicolumn{3}{|l|}{ Skin color (self-reported) } \\
\hline Dark-skinned/brown/mulatto & 363 & 61.7 \\
\hline White & 142 & 24.1 \\
\hline Black & 44 & 7.5 \\
\hline Yellow/Asian & 39 & 6.7 \\
\hline \multicolumn{3}{|l|}{ Education (years of study) ${ }^{*}$} \\
\hline$\leq 8$ & 292 & 49.7 \\
\hline$>8$ & 295 & 50.3 \\
\hline \multicolumn{3}{|l|}{ Income (minimum wages) ${ }^{\dagger \ddagger}$} \\
\hline$\leq 1$ & 84 & 14.7 \\
\hline $2-3$ & 274 & 47.9 \\
\hline$>3$ & 214 & 37.4 \\
\hline
\end{tabular}

* No data for a participant

+No data for 16 participants

$\neq$ Value of the minimum wage in Brazil, base-year 2012: $R \$ 622,00$

Table 2 - Analysis of factors associated with reporting of sexually transmitted diseases in 588 institutionalized crack users. Goiânia, GO, Brazil, 2012-2013

\begin{tabular}{|c|c|c|c|c|c|c|}
\hline \multirow{2}{*}{ Variable } & \multicolumn{2}{|c|}{ STD* } & \multirow{2}{*}{$\begin{array}{l}\mathrm{PR}^{\ddagger} \text { crude } \\
(95 \% \mathrm{Cl})^{\S}\end{array}$} & \multirow{2}{*}{$\mathbf{p}$} & \multirow{2}{*}{$\begin{array}{c}\mathrm{PR}^{\ddagger} \text { adjusted"I } \\
(95 \% \mathrm{CI})^{\S}\end{array}$} & \multirow{2}{*}{$\mathbf{p}$} \\
\hline & n/Total ${ }^{\dagger}$ & $\%$ & & & & \\
\hline \multicolumn{7}{|c|}{ Age (years) } \\
\hline$\leq 24$ & $20 / 160$ & 12.5 & 1.0 & & 1.0 & \\
\hline $25-30$ & $30 / 161$ & 18.6 & $1.5(0.9-2.5)$ & 0.10 & $2.1(1.0-4.0)$ & 0.04 \\
\hline$>30$ & $104 / 267$ & 39.0 & $3.1(2.0-4.8)$ & 0.00 & $3.8(2.1-6.8)$ & 0.00 \\
\hline
\end{tabular}


Table 2 - (continuation)

\begin{tabular}{|c|c|c|c|c|c|c|}
\hline \multirow{2}{*}{ Variable } & \multicolumn{2}{|c|}{ STD* } & \multirow{2}{*}{$\begin{array}{l}\mathrm{PR}^{\ddagger} \text { crude } \\
(95 \% \mathrm{Cl})^{\S}\end{array}$} & \multirow{2}{*}{$\mathbf{p}$} & \multirow{2}{*}{$\begin{array}{l}\mathrm{PR}^{\ddagger} \text { adjusted } \\
(95 \% \mathrm{Cl})^{\S}\end{array}$} & \multirow{2}{*}{$\mathbf{p}$} \\
\hline & n/Total ${ }^{\dagger}$ & $\%$ & & & & \\
\hline \multicolumn{7}{|l|}{ Marital status } \\
\hline Married/unmarried union & $34 / 134$ & 25.4 & 1.0 & & 1.0 & \\
\hline Single & $95 / 392$ & 24.2 & $1.0(0.7-1.3)$ & 0.80 & $1.3(0.7-2.4)$ & 0.30 \\
\hline Separated/divorced & $25 / 62$ & 40.3 & $1.6(1.0-2.4)$ & 0.03 & $1.6(0.7-3.2)$ & 0.20 \\
\hline \multicolumn{7}{|l|}{ Time of crack use(months) } \\
\hline$\leq 24$ & $42 / 191$ & 22.0 & 1.0 & & 1.0 & \\
\hline $25-48$ & $36 / 137$ & 26.3 & $1.2(0.8-1.8)$ & 0.40 & $1.2(0.7-2.1)$ & 0.50 \\
\hline$>48$ & $76 / 260$ & 29.2 & $1.3(1.0-1.8)$ & 0.09 & $0.9(0.5-1.3)$ & 0.50 \\
\hline \multicolumn{7}{|l|}{ Alcohol consumption $\pi$} \\
\hline No & $38 / 183$ & 20.8 & 1.0 & & 1.0 & \\
\hline Yes & $116 / 405$ & 28.6 & $1.4(1.0-1.9)$ & 0.05 & $1.9(1.1-3.3)$ & 0.03 \\
\hline \multicolumn{7}{|l|}{ Prison record } \\
\hline No & $66 / 297$ & 22.2 & 1.0 & & 1.0 & \\
\hline Yes & $88 / 289$ & 30.4 & $1.4(1.0-1.8)$ & 0.03 & $1.5(1.0-2.2)$ & 0.05 \\
\hline \multicolumn{7}{|c|}{ Condom use with casual partner ${ }^{\pi}$} \\
\hline Always & $37 / 150$ & 24.7 & 1.0 & & 1.0 & \\
\hline Eventually & $30 / 106$ & 28.3 & $1.1(0.8-1.7)$ & 0.50 & $0.8(0.5-1.3)$ & 0.40 \\
\hline Never & $22 / 60$ & 36.7 & $1.5(1.0-2.3)$ & 0.07 & $1.3(0.8-2.1)$ & 0.30 \\
\hline \multicolumn{7}{|l|}{ Antecedents of prostitution $\pi$} \\
\hline No & $102 / 420$ & 24.3 & 1.0 & & 1.0 & \\
\hline Yes & $40 / 111$ & 36.0 & $1.5(1.1-2.0)$ & 0.01 & $1.9(1.3-2.9)$ & 0.00 \\
\hline \multicolumn{7}{|c|}{$\begin{array}{l}\text { Gave money and drugs in exchange for } \\
\text { sex" }^{\pi}\end{array}$} \\
\hline No & $99 / 393$ & 25.2 & 1.0 & & 1.0 & \\
\hline Yes & $46 / 142$ & 32.4 & $1.3(1.0-1.7)$ & 0.09 & $1.3(0.9-2.0)$ & 0.20 \\
\hline \multicolumn{7}{|c|}{$\begin{array}{l}\text { Sexual intercourse with a person living } \\
\text { with HIVIAIDS** }\end{array}$} \\
\hline No & $110 / 486$ & 22.6 & 1.0 & & 1.0 & \\
\hline Yes & $15 / 24$ & 62.5 & $2.8(1.9-3.9)$ & 0.00 & $2.7(1.8-4.2)$ & 0.00 \\
\hline
\end{tabular}

*Sexually Transmitted Disease

tDenominator reflects the number of valid responses

¥Prevalence Ratio

§Confidence interval of $95 \%$

IIAjusted by age, marital status, time of crack use, alcohol consumption, prison record, condom use with casual partner, antecedents of prostitution and sexual intercourse with a person living with HIV/AIDS

ILast six months

$* *$ Last year

\section{Discussion}

In Brazil, there are few studies of crack users $(5,10,15)$. This research presents the first data on STD reporting in crack users in the Central-West region of Brazil. The study population consisted predominantly of males, young adults, singles and with low income, which are characteristics common to institutionalized crack users from other regions of Brazil(15-16).

The STD reporting in vulnerable populations, such as crack users, can contribute to the screening of the positive and symptomatic cases, the access to health services and the specific diagnosis of the etiologic agent, reducing the chain of transmission in this population group. Furthermore, interventions for the treatment and control of STD by professionals and health services may occur from the verbal reporting on these infections.

In this study, the prevalence of STD reporting was of $26.2 \%$ (95\% CI: $22.8-29.9$ ), similarly to that found in institutionalized drug users in the northern of Thailand $(n=1859 ; 24.3 \% ; 95 \% \text { CI: 22.4-26.3) })^{(17)}$. However, it was lower than estimated for female drug users of Baltimore $(n=214 ; 40.7 \% ; 95 \%$ CI: 34.3-47.3)(18) and non institutionalized crack users of Miami and Florida $(n=2002$; 51.4\%; 95\% CI: 49.3-53.6), USA(12).The differences in the prevalence rates reported in Goiannia and in the USA may be explained by the higher frequency of risk factors in these populations, such as prison record, prostitution and alcohol consumption ${ }^{(12,18)}$. Regarding the study in Baltimore ${ }^{(18)}$, women were biologically more susceptible to STD, prostituting themselves more than men. 
On the other hand, the prevalence found in Goiás was similar to that observed in institutionalized illicit drug users in São Paulo, Southeastern region of Brazil $(n=304 ; 22 \% ; 95 \% \mathrm{CI}: 17.8-27.0)^{(9)}$ and crack users assisted in Centers for Psychosocial Attention of the state of Piauí, Northeast region of Brazil $(n=352$; $31.2 \%$; 95\% CI: $26.6-36.3)^{(15)}$. A study to estimate the prevalence of $\mathrm{HCV}$ infection in institutionalized illicit drug users of Campo Grande and Goiânia, in the Central-West region of Brazil, found a frequency of STD reporting of $30.9 \%(n=664 ; 95 \% \mathrm{CI}: 27.5-34.5)^{(19)}$.

In the present study, STD reporting was independently associated with age, alcohol consumption, antecedents of prostitution and intercourse with a person living with HIV/AIDS. Moreover, prison record remained marginally associated with the outcome.

It was observed a positive gradient of STD reporting and age, with prevalence increase from $12.5 \%$ in individuals younger than 25 years, to $39.0 \%$ in users over 30 years. (Prevalence Ratio: 3.8: 95\% CI: 2.16.8 ), which suggests a cumulative risk of acquiring STD as age increases. Other authors have also pointed age as predictor of STD in illicit drug users $(7,20)$.

Of all participants, $68.9 \%$ (95\% CI: 65.0-72.5), 63.6\% (95\% CI: 59.6-67.4) and 55.4\% (95\% CI: 51.4$59.4)$ reported, in the last six months, consumption of alcohol, marijuana and snorted cocaine, respectively, which classifies them as polyusers. In addition, STD reporting was associated with alcohol consumption (Prevalence Ratio: 1.9; 95\% CI: 1.1-3.3). The consumption of alcohol and crack favors the adoption of risky sexual practices, such as multiple sexual partners, prostitution, inconsistent condom use and sexual intercourse with STD carriers ${ }^{(6,21)}$, increasing the vulnerability of crack users to infection through sexual transmission.

Antecedents of prostitution was reported by $18.9 \%$ (95\% CI: $15.9-22.2$ ) of users. This feature was associated with STD reporting (Prevalence Ratio: 1.9; 95\% CI: 1.3-2.9). A study conducted with 407 drug users in two cities in Texas, USA, showed an association between preferred use of crack, prostitution and increased prevalence of STD(13). Prostitution is an alternative for the users to obtain drugs $^{(4)}$ and/or money(22) for drug purchase, leading to a high risk of STD acquisition by this population group.

Approximately $4.1 \%$ (95\% CI: $2.8-6.0)$ of the participants reported to have hadsex with individuals living with HIV/AIDS, and of these, half did not use condoms. It was also observed an association between antecedents of sexual relations with people living with HIV/AIDS and STD reporting (prevalence ratio: 2.7: 95\% CI: 1.8-4.2). In the USA, an investigation carried out with young people, showed higher prevalence of reporting of sexual relationship with STD carriers among crack and non-injectable cocaine users ${ }^{(6)}$.Furthermore, a study carried out in Nassau, Bahamas, showed a temporal relationship between crack epidemic and increasing cases of genital ulcers, secondary syphilis and $\mathrm{HIV}^{(23)}$, showing a strong association between crack use and spread of STD.

Crack use is often related to illicit practices, with antecedents of arrest and/or imprisonment, common in this population ${ }^{(9)}$. In the present study, approximately half $(49.1 \% ; 95 \% \mathrm{CI}: 45.1-53.2)$ of individuals reported antecedents of imprisonment. Yet, it was found that crack users with prison records showed prevalence ratio 1.5 times higher (95\% CI: 1.0-2.2) than those who did not report this feature. Other authors also have reported incarceration as predictor of STD in illicit drug users $^{(8,20)}$. In general, individuals incarcerated have high rates of STD ${ }^{(24)}$ and multiple risk behaviors that favor the transmission of these infections ${ }^{(25)}$.

The findings of this study suggest that multiple factors must be considered in the integral care of the crack users, including the tracking of these infections. The nurses and the multidisciplinary health team should consider the vulnerabilities and risks of these individuals for STD in the care planning, with emphasis on health education activities, availability of rapid tests for detection of these diseases, early treatment and hepatitis B vaccination, provision of condoms and supplies for prevention, and epidemiological surveillance.

This research has some limitations that should be considered. Due to the nature of data collection, the prevalence of STD reporting can be under-or overestimated. In addition, response bias should be considered for sensitive moral issues. However, it should be noted that the results of this study are in agreement with the literature, and suggest a high prevalence of STD in crack users investigated.

\section{Conclusion}

In this study, prevalence of STD reporting was of $26.2 \%$ (95\% CI: 22.8-29.9) and independently associated with ages between 25 and 30 years, over 30 years, alcohol consumption, antecedents of prostitution 
and sexual intercourse with a person living with HIV/ AIDS.

The results of this study suggest high risk and vulnerability of crack users for STD. Consequently, public policies and strategies for control and prevention of diseases associated with crack use, such as the implementation of policies for reducing the damage caused by alcohol and other drugs, as well as health education, should be a priority for this population.

The knowledge of serological and epidemiological profiles of infections in different populations can contribute in a unique way in the planning and implementation of actions to promote health and disease prevention, as well as in the health care for people in a comprehensive and holistic manner, respecting the particularities of each segment of the population. Healthcare professionals should always seek this knowledge for decision-making based on evidence when assisting the individual, the family and the community.

\section{Acknowledgements}

To the team of the Center for Studies in Epidemiology and Infectious Diseases Care, with emphasis on viral hepatitis (NECAIH/FEN/UFG) and to the Research Group Study of Viral Hepatitis in the Central-West region of Brazil (IPTSP/UFG) for logistical support and data collection.

\section{References}

1. United Nations Office on Drugs and Crime (USA). World Drug Report 2012 [Internet]; 2012. [cited Jan 14 2014]. Avaliable from: http://www.unodc.org/documents/dataand-analysis/WDR2012/WDR_2012_web_small.pdf

2. Ministério da Saúde (BR). Secretaria de Vigilância em Saúde. Departamento de DST, Aids e Hepatites Virais. Pesquisa de Conhecimentos, Atitudes e Práticas na População Brasileira de 15 a 64 anos 2008. [Internet]; 2011. [cited Dec 23 2013]. Avaliable from: http://www.aids.gov.br/sites/default/files/anexos/ publicacao/2009/40352/pcap_2008_f_pdf_13227.pdf

3. Riezzo I, Fiore C, De Carlo D, Pascale N, Neri M, Turillazzi $E$, et al. Side effects of cocaine abuse: multiorgan toxicity and pathological consequences. Curr Med Chem. 2012; 19(33):5624-46.

4. Dualibi LB, Ribeiro M, Laranjeira R. Profile of cocaine and crack users in Brazil. Cad Saúde Pública. 2008;24 Suppl 4:545-55.
5. Azevedo RC, Botega NJ, Guimarães LAM. Crack users, sexual behavior and risk of HIV infection. Rev Bras Psiquiatr. 2007;29(1):26-30.

6. Khan MR, Berger A, Hemberg J, O'Neill A, Dyer TP, Kmyrk K. Non-Injection and Injection Drug use and STI/HIV Risk in the United States: the Degree to which Sexual Risck Behaviors Versus Sex with an STI-Infected Partner Account for Infection Transmission among Drug Users. AIDS Behav. 2013;17(3):1185-94.

7. Hwang LY, Ross MW, Zack C, Bull L, Rickman K, Holleman M. Prevalence of Sexually Transmitted Infections and Associated Risk Factors among Populations of Drug Abusers. Clin Infect Dis. 2000; 31(4):920-6.

8. Rossi D, Rudulich G, Muzzio E, Naveira J, Sosa-Estani $\mathrm{S}$, Rey J, et al. Multiple infections and associated risk factors among non-injecting cocaine users in Argentina. Cad Saúde Pública. 2008;24(5):965-74.

9. Carvalho HB, Seibel SD. Crack Cocaine Use and Its Relationship With Violence and HIV. Clinics. 2009; 64(9):857-66.

10. Nunes CLX, Andrade T, Galvão-Castro B, Bastos FI, Reingold A. Assessing risk behaviors and prevalence of sexually transmitted and blood-borne infections among female crack cocaine users in Salvador - Bahia, Brazil. Braz J Infect Dis. 2007;11(6):561-6.

11. Des Jarlais DC, Arasteh K, McKnight C, Perlman $D$, Hagan $H$, Semaan $S$, et al. Gender and Age Patterns in HSV-2 and HIV Infection Among NonInjecting Drug Users in New York City. Sex Transm Dis. 2010;37(10):637-43.

12. MacCoy CB, Lai S, Metsch LR, Messiah SE, Zhao W. Injection Drug use and Crack Cocaine Smoking: Independent and Dual Risk Behaviors for HIV infection. Ann Epidemiol. 2004;14(8):535-42.

13. Ross MW, Hwang LY, Zack C, Bull L, Willians ML. Sexual risk behaviours and STIs in drug abuse treatment populations whose drug of choise is crack cocaine. Int J STD AIDS. 2002;13(11):769-74.

14. Fundação Oswaldo Cruz (BR). Ministério da Saúde. Secretaria Nacional de Políticas sobre Drogas. Ministério da Justiça. Perfil dos Usuários de crack e/ ou similares no Brasil. [Internet]; 2013. [cited Jan 14 2014]. Avaliable from: http://www.casacivil.gov.br/ noticias/perfil-brasil.pdf

15. Sá LC, Araújo TM, Griep RH, Campelo V, Monteiro CF. Seroprevalence of Hepatitis $C$ and factors associated with this in crack users. Rev. Latino-Am. Enfermagem. 2013; 21(6):1195-202.

16. Oliveira EM, Nogueira NF, Marinho MP, Nogueira DL, Rocha NNV, Duarte SR. Characterization of Crack 
Users served in CAPS for alcohol and other drugs. J Nurs UFPE on line. [Internet]. 2012 [cited Jan 14 2014]; 6(9):2093-102. Avaliable from: http://www.revista. ufpe.br/revistaenfermagem/index.php/revista/article/ viewFile/2776/pdf_1439

17. Jittiwutikarn J, Thongsawat $S$, Suriyanon V, Maneekarn N, Celentano D, Razak MH, et al. Hepatitis C Infection among drug users in Northern Thailand. Am J Trop Med Hyg. 2006; 74(6):1111-6.

18. Cavanaugh CE, Floyd LJ, Penniman TV, Hulbert A, Gaydos C, Latimer WW. Examining racial/ethnic disparities in sexually transmitted diseases among recent heroin-using and cocaine-using women. J Womens Health (Larchmt). 2011;20(2):197-205.

19. Lopes CLR, Teles SA, Espírito-Santo MP, Lampe E, Rodrigues FP, Motta-Castro ARC, et al. Prevalence, risk factors and genotypes of hepatitis $C$ virus infection among drug users, Central-Western Brazil. Rev Saúde Pública. 2009;43 Suppl 1:43-50.

20. Plitt SS, Sherman SG, Strathdee SA, Taha TE. Herpes simplex virus 2 and syphilis among young drug users in Baltimore, Maryland. Sex Transm Infect. 2005;81(3):248-53.

21. Dickson-Gomez J, McAuliffe T, Rivas de Mendoza L, Glasman L, Gaborit M. The relationship between community structural characteristics, the context of crack use, and HIV risk behaviors in San Salvador, El Salvador. Subst Use Misuse. 2012;47(3):265-77.

22. Brewer TH, Zhao W, Metsch LR, Coltes A, Zenilman J. High-risk behaviors in women who use crack: knowledge of HIV serostatus and risk behavior. Ann Epidemiol. 2007; 17(7):533-9.

23. Gomez PM, Kimball AM, Orlander H, Bain, RM, Fisher LD, Holmes KK. Epidemic crack cocaine use linked with epidemics of genital ulcer disease and heterosexual HIV infection in the Bahamas: evidence of impact of prevention and control measures. Sex Transm Dis. 2002; 29(5):259-64.

24. Sagnelli E, Starnini G, Sagnelli C, Monarca R, Zumbo $G$, Pontali $E$, et al. Blood born viral infections, sexually transmitted diseases and latent tuberculosis in italian prisons: a preliminar report a large multicenter study. Eur Rev Med Pharmacol Sci. 2012;16(15):2142-6.

25. Kazi AM, Shah SA, Jenkins CA, Shepherd BE, Vermund $\mathrm{SH}$. Risk factors and prevalence of tuberculosis, human immunodeficiency virus, syphilis, hepatitis B virus, and hepatitis $C$ virus among prisoners in Pakistan. Int J Infect Dis. 2010;14 Suppl 3:60-6. 